J. Pijar MIPA, Vol. VI No.2, September :65- 73

ISSN 1907-1744

\title{
UPAYA MENINGKATKAN KUALITAS PROSES DAN HASIL BELAJAR KIMIA DASAR I DENGAN PENERAPAN METODE INKUIRI TERBIMBING DENGAN KEGIATAN LABORATORIUM MAHASISWA PROGDI. PEND. KIMIA, PMIPA FKIP UNRAM, TH 2011/12
}

\author{
Oleh \\ Jeckson Siahaan ${ }^{1}$, Muti'ah $^{1}$, Sukib $^{1}$ \\ Program Studi Pendidian Kimia FKIP Universitas Mataram, Mataram \\ e-mail: siahaan_jacko@yahoo.com
}

\begin{abstract}
Abstrak : Penelitian tentang pembelajaran inkuiri terbimbing dengan kegiatan laboratorium untuk meningkatkan kualitas pembelajaran kimia dasar I mahasiswa Program Studi Pendidikan Kimia FKIP Universitas Mataram. Tujuan penelitian ini untuk meningkatan aktivitas pembelajaran mahasiswa, hasil belajar, dan motivasi belajar siswa setelah diberi tindakan pembelajaran inkuiri terbimbing dengan kegiatan laboratorium. Metode yang digunakan mengacu pada prosedur penelitian tindakan kelas selama 2 siklus yang merupakan siklus dari perencanaan, tindakan, observasi, refleksi, analisis dan evaluasi. Sikus I (prinsip Le Chatelier), siklus II (tetapan kesetimbangan, $\mathrm{Kc}$ ). Hasil dari penelitian menunjukkan bahwa pembelajaran inkuiri terbimbing dengan kegiatan laboratorium pada pengajaran kimia dapat: (1) meningkatkan aktivitas pembelajaran yang secara kuantitatif mencapai 60,33\% (siklus 1(1), 68,66\% (siklus 1(2) dan 85,33\% (siklus 2), (2) meningkatkan prestasi belajar dari 57,19 (siklus 1) hingga 71,20 pada siklus 2, (3) meningkatkan motivasi belajar yang ditunjukkan sebesar 26,2\% mahasiswa menyatakan sangat setuju, 63,8\% setuju, $7,7 \%$ kurang setuju dan 2,2\% tidak setuju. Kesimpulan yang diperoleh dari penelitian ini bahwa pembelajaran inkuiri terbimbing dengan kegiatan laboratorium pada pengajaran kimia dapat meningkatkan aktivitas, motivasi dan hasil belajar siswa.
\end{abstract}

Kata kunci: Pembelajaran inkuiri terbimbing, laboratorium, prinsip Le Chatelier, tetapan kesetimbangan

\begin{abstract}
Research on guided inquiry learning with laboratory activities to improve the quality of learning basic chemistry I students of Chemistry Education Department the Faculty of Teacher Training Education, University of Mataram . The purpose of this research is to improve student learning activities, learning outcomes, and the motivation to study after being given a guided inquiry learning with laboratory activities. The method used is based on action research procedures in two cycles that the cycle of planning, action, observation, reflection, analysis and evaluation. Sikus I (Le Chatelier's principle ), second cycle (the equilibrium constant, Kc). The results of the study indicate that the guided inquiry learning with laboratory activities can: (1) improve the learning activity quantitatively reached $60.33 \%$ (cycle 1 (1), $68.66 \%$ (cycle 1 (2) and $85.33 \%$ (cycle 2), (2) improve the learning achievement of 57.19 (cycle 1) to 71.20 in cycle 2 , (3) increase learning motivation demonstrated by $26.2 \%$ of students stated strongly agreed, $63.8 \%$ agree, $7.7 \%$ litle disagree and $2.2 \%$ disagree. Conclusions obtained from this research that guided inquiry learning with laboratory activities can enhance the activity, motivation and student learning outcomes.
\end{abstract}

Keywords : guided inquiry learning, laboratory, Le Chatelier's principle, the equilibrium constant

\section{PENDAHULUAN}

Penelitian ini dilatarbelakangi oleh rendahnya hasil belajar kimia maupun kemampuan melakukan percobaan kimia (psikomotorik) Mahasiswa Program Studi Pendidikan Kimia, FKIP Unram. Kondisi tersebut dapat disebabkan oleh metode pembelajaran yang diterapkan selama ini, yaitu metode ceramah dengan sedikit latihan dan diakhiri dengan tes .

Hasil diskusi antara Tim dosen pengampu mata kuliah Kimia dasar I dapat diidentifikasi beberapa masalah yang terjadi selama proses pembelajaran di kelas, yaitu: (1) aktivitas belajar siswa rendah, (2) mahasiswa mudah lupa dengan konsep yang dijelaskan oleh dosen, (3) mahasiswa merasa canggung untuk melakukan percobaan kimia, (4) dosen memerlukan suatu metode pembelajaran yang melibatkan kegiatan di laboratorium.

Untuk mengatasi permasalahan tersebut di atas maka perlu diterapkan metode pembelajaran dimana pengetahuan dan ketrampilan siswa diperoleh dari hasil menemukan sendiri (metode pembelajaran inkuiri) [1]. Akibatnya dengan keterlibatan aktif siswa dalam proses menkonstruk pengetahuannya, maka 
J. Pijar MIPA, Vol. VII No.2, September : 65 - 73

akan terjadi peningkatan pemahaman, dan ketrampilan berpikir kritis [2].

Dari hasil studi literatur telah dilaporkan bahwa metode pembelajaran inkuiri melalui kegiatan laboratorium cukup baik untuk pembelajaran kimia, misalnya Davodowitz dan Rollnick [3] untuk topik siklus reaksi tembaga, Bowen dan Phelps [4] identifikasi asam dan penentuan konsentrasi asam, dan Rollinck et al. [5] untuk reaksi pengendapan.

Sehubungan dengan hal tersebut di atas, konsep kesetimbangan kimia bagi mahasiswa yang mengikuti kuliah Kimia Dasar I termasuk materi yang sulit dipahami terutama dalam memahami pengertian reaksi setimbang, pergeseran kesetimbangan/prinsip Le Chartelier's, dan pengertian tetapan Kc. Hal tersebut sesuai dengan hasil penelitian Huddle dan Pillay [6] bahwa kesalahan konsep siswa dalam memahami kesetimbangan kimia karena bersifat abstrak. Selanjutnya Quilez [7] menemukan kesalahan konsep siswa terletak pada pemahaman prinsip Le Chatelier's dan pengertian Kc.

Untuk mengatasi permasalahan tersebut diperlukan tindakan dengan menerapkan metode pembelajaran inkuiri terbimbing dengan kegiatan di laboratorium [8]. Bimbingan atau arahan yang diberikan dosen kepada mahasiswa selama proses kegiatan pembelajaran antara lain diwujudkan dalam lembar kerja siswa LKS yang berisi permasalahan yang akan dibahas secara sistematis.

Tujuan dari penelitian ini adalah terwujudnya peningkatan aktivitas, motivasi dan hasil belajar kimia dasar I bagi mahasiswa setelah diterapkan metode pembelajaran inkuiri terbimbing melalui kegiatan di laboratorium.

\section{METODE PENELITIAN}

\section{Subyek, Waktu, dan Tempat Penelitian}

Subyek dalam penelitian ini adalah mahasiswa Program studi Pendidikan Kimia FKIP Unram yang sedang mengambil matakuliah Kimia Dasar I. Waktu pelaksanaan penelitian adalah di semester ganjil pada bulan September- Desember 2011 dengan 2 siklus sesuai dengan kompetensi yang harus dikuasai siswa. Siklus I dilaksanakan 2 pertemuan (Pergeseran Kesetimbangan/ Prinsip Le Chaterlier's), dan siklus II dilaksanakan 1 pertemuan (Pengertian Kc). Tempat penelitian adalah Program Studi Pendidikan Kimia, PMIPA, FKIP Unram.

\section{Langkah-langka Penelitian}

Penelitian ini merupakan jenis penelitian tindakan kelas (classroom action research). Prosedur tindakan merupakan siklus dari: (1) Perencanaan tindakan; (2) Pelaksanaan tindakan; (3) Observasi (4) Evaluasi-Refleksi tindakan [9].

Tindakan yang diterapkan adalah pembelajaran inkuiri terbimbing dengan kegiatan laboratorium dalam upaya meningkatkan kualitas pembelajaran kimia dasar 1.

\section{Perencanaan Tindakan}

Tahap perencanaan tindakan merupakan persiapan yang dilakukan sebelum pembelajaran dilaksanakan, yaitu:

Pembuatan perangkat pembelajaran:

Rencana pembelajaran, lembar kerja siswa berisi prosedur kerja hingga lembar pengamatan secara lengkap, dan peralatan serta bahan percobaan

(2) Pembuatan seperangkat alat instrumen: Lembar observasi, lembar penilaian kerja siswa selama melakukan percobaan (assesmen kinerja), tes hasil belajar dan angket tentang tanggapan siswa terhadap model pembelajaran yang dilaksanakan.

\section{Tahap Pelaksanaan Tindakan}

Pelaksanaan tindakan dilakukan oleh Tim peneliti (Peneliti adalah 1 dosen dan 2 orang dosen) dengan menerapkan pembelajaran inkuiri terbimbing dengan kegiatan laboratorium pada topik pergeseran kesetimbangan kimia/ prinsip Le Chatelier's dengan langkah-langkah:

(1) Sebelum pembelajaran dimulai (minimal sehari sebelum kegiatan pembelajaran) dosen dan atau dosen membagikan lembar kerja siswa (LKS) yang berisi percobaan pergeseran kesetimbangan kimia, membagi kelompok kerja dengan jumlah 4 siswa per kelompok, dan mempersiapkan alat dan bahan percobaan

(2) Pembelajaran pergeseran kesetimbangan dilakukan oleh seluruh tim peneliti ( 1 dosen dan 2 dosen) setiap orang membimbing sekitar 3 kelompok kerja. Tahapan yang dilakukan adalah sebagai berikut:

Tahap orientasi (selama 20 menit): seorang dosen atau dosen memberi orientasi umum tentang konsep yang dipelajari, isi LKS, serta proses kegiatan percobaan di laboratorium

Tahap pelaksanaan (selama 1 jam): Siswa melakukan percobaan sesuai dengan petunjuk, mencatan hasil percobaan, menginterpretasi data dengan cara mengisi pertanyaan dan menyimpulkan yang seluruhnya sudat tersedia dalam LKS. 
Fungsi dosen dan dosen adalah membimbing dan mengatasi kesulitan siswa selama melakukan kegiatan pembelajaran.

Tahap restrukturisasi: dosen/dosen merestrukturisasi konsep konsep yang diperoleh siswa dengan cara salah satu kelompok menyampaikan hasil percobaannya dan kelompok lain ditugaskan memberi tanggapan.

Tahap pemantapan konsep: dosen menugaskan kepada siswa untuk mengerjakan latihan-latihan, sehingga konsep yang dimiliki siswa lebih mantap.

\section{Tahap Observasi Tindakan}

Pada tahap ini dilakukan observasi oleh dosen terhadap proses belajar mengajar yang sedang berlangsung, dengan tujuan untuk mengetahui aktivitas siswa dan kendala-kendala yang dihadapi. Selama kegiatan pembelajaran dosen menilai hasil kerja siswa yang disajikan dalam bentuk asesmen kinerja kerja.

Pada akhir siklus dilakukan pengukuran terhadap hasil belajar siswa dan pendapat mahasiswa terhadap pembelajaran yang diterapkan dengan menggunakan angket. Data yang diperoleh dari penelitian tindakan ini terdiri dari data kualitatif dan kuantitatif.

\section{Evaluasi dan Refleksi}

Data kualitatif maupun kuantitatif yang berupa aktivitas selama proses pembelajaran, hasil assesmen kerja siswa, hasil belajar, dan hasil tes angket tentang tanggapan siswa terhadap pembelajaran yang diterapkan selanjutnya dianalisis dan dievaluasi oleh tim peneliti. Hasil yang diperoleh baik kelebihan dan kekurangannya dikaji untuk dijadikan dasar perbaikkan pada pertemuan-pertemuan /siklus berikutnya.
Hasil analisis, evaluasi dan refleksi pada siklus I selanjutnya dijadikan dasar untuk pelaksanaan siklus II (Penenetuan tetapan $\mathrm{Kc}$ ) yang dilaksanakan dalam 1 pertemuan. Tindakan yang dilakukan adalah sama yaitu pembelajaran inkuiri terbimbing dengan kegiatan laboratorium

\section{Analisis Data Hasil Penelitian}

Data yang dihasilkan di setiap siklus selanjutnya dianalisis, sehingga diperoleh kesimpulan yang tepat. Data yang dianalisis terdiri dari:

(1) Data kualitatif: terutama mengenai aktivitas siswa dalam mengikuti pembelajaran dan dijelaskan secara naratif.

Data kuantitatif: terutama adalah nilai ratarata hasil kerja dilaboratorium (asesmen kinerja), hasil belajar (tes kemampuan), nilai rata-rata hasil angket tentang tanggapan siswa terhadap pembelajaran yang diterapkan.

\section{HASIL DAN PEMBAHASAN}

\section{Hasil Penelitian}

Beberapa hal yang dikaji dalam penelitian ini adalah untuk mengungkap peningkatan aktivitas menemukan konsep, prestasi belajar dan sikap mahasiswa pada pembelajaran kesetimbangan kimia setelah siswa diberi tindakan pembelajaran inkuiri terbimbing dengan kegiatan laboratorium. Penelitan dilakukan dalam 2 siklus, yaitu siklus - I (dua pertemuan) dan siklus II (satu pertemuan). Hasil kuantitatif mengenai aktivitas pembelajaran dapat dilihat dalam tabel -1 .

Tabel 1. Nilai Kuantitatif Aktivitas Proses Inkuiri/Penemuan Konsep

\begin{tabular}{llccc}
\hline No & Aktivitas yang diamati & \multicolumn{3}{c}{ Kegiatan } \\
\cline { 3 - 5 } & & Siklus $-1: 1$ & Siklus $-1: 2$ & Siklus -2 \\
\hline 1 & Menggunakan alat & 2,00 & 2,10 & 2,56 \\
2 & Mengamati & 1,70 & 2,00 & 2,30 \\
3 & Mengumpulkan data & 1,90 & 2,20 & 2,70 \\
4 & Menginterpretasi data & 1,50 & 1,90 & 2,64 \\
5 & Menyimpulkan & 1,95 & 2,10 & 2,60 \\
\hline & Rata- rata & $\mathbf{1 , 8 1}(\mathbf{6 0 0 , 3 3 \% )}$ & $\mathbf{2 , 0 6}(\mathbf{6 8 , 6 6 \% )}$ & $\mathbf{2 , 5 6 ( 8 5 , 3 3 \% )}$ \\
& & (kurang benar) & (kurang benar) & (benar) \\
\hline
\end{tabular}

Keterangan: nilai (1) Tidak benar, (2) kurang benar, dan (3) benar 
J. Pijar MIPA, Vol. VII No.2, September : 65 - 73

Berdasarkan data tersebut menunjukkan adanya peningkatan nilai aktivitas dalam menemukan konsep, yaitu siklus 1- 1 sebesar $(1,8)$ siklus 1-2 (2,06), dan siklus 2 sebesar 2,56. Hal ini menunjukkan bahwa ketrampilan mahasiswa dalam melakukan penemuan/inkuiri adalah meningkat, namun belum mencapai kebenaran $100 \%$. Sebagai contoh pada akhir siklus 3 hanya bernilai 2,56 sedangkan kategori benar adalah 3, sehingga mengandung arti bahwa mahasiswa yang tepat benar melakukan proses inkuiri hanya 85,33\%, sedangkan untuk siklus $1(1)$ sebesar 60,33\%, dan siklus $1(2)$ sebesar $68,66 \%$

Selanjutnya nilai rata-rata prestasi belajar mahasiswa siklus I dan II dapat dilihat dalam tabel 2. berikut

Tabel 2. Nilai Prestasi Belajar Mahasiswa Selama Pembelajaran

\begin{tabular}{lccc}
\hline \multicolumn{1}{c}{ Nilai } & Siklus - I & Siklus - II \\
\hline Nilai rata-rata & 57,19 & 71,20 & \\
Standar deviasi & 16,93 & 16,43 & \\
\hline
\end{tabular}

Berdasarkan data pada tabel 2, maka nilai hasil belajar pada siklus II lebih tinggi dari siklus I dan nilai standar deviasi atau keragamannya menurun. Selanjutnya nilai motivasi siswa terhadap metode pembelajaran yang digunakan dapat dilihat dalam tabel 3 berikut ini.

Tabel 3. Nilai Sikap Mahasiswa Terhadap Pembelajaran

\begin{tabular}{|c|c|c|c|c|c|}
\hline \multirow[t]{2}{*}{ No } & \multirow[t]{2}{*}{ Kriteria yang di uji } & \multicolumn{4}{|c|}{ Persentase } \\
\hline & & 1 & 2 & 3 & 4 \\
\hline 1 & $\begin{array}{l}\text { Konsep kesetimbangan kimia sangat tepat diajarkan dengan metode } \\
\text { eksperimen }\end{array}$ & 30 & 61 & 9 & 0 \\
\hline 2 & $\begin{array}{l}\text { Agar dapat memahami apa yang dilakukan, sebaiknya percobaan kimia } \\
\text { dibimbing oleh seorang dosen }\end{array}$ & 62 & 30 & 4 & 4 \\
\hline 3 & $\begin{array}{l}\text { Dengan melakukan percobaan, saya dapat menemukan konsep - konsep } \\
\text { yang lebih jelas tentang kesetimbangan kimia }\end{array}$ & 26 & 70 & 4 & 0 \\
\hline 4 & $\begin{array}{l}\text { Dengan melakukan percobaan yang sistematik saya merasa lebih mudah } \\
\text { memahami konsep abstrak dalam kesetimbangan kimia }\end{array}$ & 0 & 96 & 4 & 0 \\
\hline 5 & $\begin{array}{l}\text { Dalam menemukan konsep kimia melalui percobaan, dimnbimbing oleh Co } \\
\text { Ast sama saja dengan dibimbing oleh seorang dosen }\end{array}$ & 4 & 69 & 17 & 9 \\
\hline 6 & $\begin{array}{l}\text { Selama saya melakukan percobaan kimia, baru kali ini saya paham bahwa } \\
\text { dengan melakukan pengamatan yang baik, perhitungan yang tepat saya } \\
\text { dapat menemukan konsep dengan baik }\end{array}$ & 35 & 57 & 8 & 0 \\
\hline & Rata-rata & 26,2 & 63,8 & 7,7 & 2,2 \\
\hline
\end{tabular}

Keterangan: (1) sangat setuju, (2) setuju, (3) kurang setuju, (4) tidak setuju

Berdasarkan data tabel 3 menunjukkan bahwa jumlah mahasiswa yang tidak setuju terhadap pembelajaran yang diterapkan hanya sebesar $2,2 \%$, kurang setuju $7,7 \%$, setuju $63,8 \%$, dan sangat setuju sebesar $26,2 \%$

\section{Pembahasan}

\section{Aktivitas Pembelajaran}

Aktivitas pembelajaran dalam penelitian ini adalah kegiatan inkuiri bagi mahasiswa untuk menemukan konsep tentang pergeseran kesetimbangan. Aktivitas tersebut ditunjukkan oleh kemampuan mahasiswa dalam: (1) menggunakan alat/melakukan percobaan, (2) mengamati, (3) menyajikan/mengumpulkan data, (4) menginterpretasi dan (5) membuat kesimpulan. Aktivitas mahasiswa tersebut diamati untuk 3 kegiatan inkuiri, yaitu mendeskripsikan pergeseran sistem kromat-bikromat, sistem Fe-tiosianat, dan persamaan Kc pada sistem kesetimbangan Fe-tiosianat.
Untuk kegiatan siklus 1(1) aktivitas yang dinilai meliputi cara mereaksikan ion kromat dengan asam $\mathrm{H}^{+}$atau $\mathrm{OH}^{-}$, mengamati perubahan warna yang terjadi yaitu dari kuning ke oranye, mencatat hasil pengamatan, mengartikan hubungan antara terbentuknya warna dengan keberadaan melekul yang ada dalam sistem tersebut, dan menyimpulkan tentang definisi pergeseran kesetimbangan. Nilai aktivitas mahasiswa dari terendah adalah interpretasi data - pengamatan - pengumpulan - menyimpulkan - menggunakan alat. 


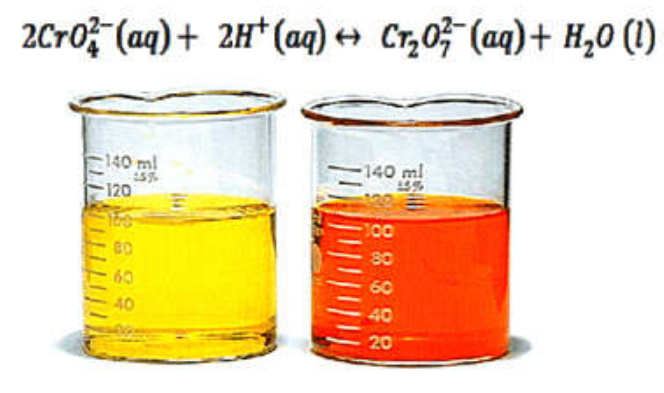

Gambar 1: Proses inkuiri siklus 1 (1), kesetimbangan sistem ion kromat - bikromat

Berdasarkan hasil penelitian menunjukkan bahwa sebagian besar mahasiswa belum dapat mengiterpretasi/ mengartikan antara pembentukan/perubahan warna yang dalam sistem dengan keberadaan molekul, dan keberadaan molekul diakibatkan adanya reaksi pembentukan molekul tersebut. Terjadinya reaksi pembentukan atau arah reaksi dalam sistem setimbang disebut pergeseran kesetimbangan. Dalam kasus sistem kromat - bikromat, adanya penambahan ion $\mathrm{H}^{+}$berakibat warna larutan menjadi oranye, warna oranye merupakan akibat dari terbentuknya molekul dikromat. Dengan demikian adanya ion $\mathrm{H}+$ maka akan terjadi reaksi ke pembentukan molekul molekul bikromat yang berwarna oranye. Proses atau reaksi kimia tersebut dinyatakan dalam sutu persamaan

$2 \mathrm{CrO}_{4}^{2-}(a q)+2 \mathrm{H}^{+}(a q) \leftrightarrow \mathrm{Cr}_{2} \mathrm{O}_{7}^{2-}(a q)+\mathrm{H}_{2} \mathrm{O}(\mathrm{l})$

Dengan demikian karena pemebentukan molekul dikromat berada di sisi kanan persamaan reaksi, maka dikatakan reaksi bergeser ke kanan.

Rendahnya kemampuan mahasiswa dalam melakukan pengamatan dapat disebabkan oleh kurangnya pengetahuan dasar yang dimiliki, dalam hal ini mereka belum mengetahui apa maksud pengamatan perubahan warna dikaitkan dengan konsep yang dipelajari. Dari kelemahan tersebut selanjutnya dosen memberi penekanan dalam siklus 2 terutama dalam meninterpretasi data dengan cara memberi penjelasan yang bersifat molekuler dalam sistem kesetimbangan.

Untuk kegiatan siklus 1 (2) yaitu aktivitas inkuiri dalam mengamati pergeseran kimia sistem Fe-tiosianat akibat adanya ion - ion yang ada menunjukkan bahwa aktivitas meningkat dibandingkan dengan siklus 1 (1) yaitu dari rata rata $1,81(60,33 \%)$ menjadi 2,06 (68,67\%). Namun demikian untuk kemampuan interpretasi data masih tergolong kurang.

Kasus kesulitan interpretasi data dalam siklus 1 (2) hampir sama dengan kasus pada siklus 1(1). Dalam kasus ini mahasiswa mengamati sistem kesetimbangan pada gambar 2 dengan persamaan reaksi sebagai berikut

$$
\begin{array}{ll}
\mathrm{Fe}^{3+}(a q)+\mathrm{SCN}^{-}(a q) & \rightarrow \mathrm{FeSCN}^{2+}(a q) \\
\text { kuning tak berwarna } & \text { merah darah }
\end{array}
$$

Aksi yang diberikan pada sistem tersebut adalah: penambahan ion $\mathrm{Fe}^{3+}$, penambahan ion $\mathrm{CNS}^{-}$dan pengurangan ion $\mathrm{CNS}^{-}$melalui penambahan ion $\mathrm{Ag}^{+}$. Sebagaimana sistem kromat - bikromat, maka penambahan ion $\mathrm{Fe}^{3+}$ maupun ion $\mathrm{CNS}^{-}$adalah akan mengakibatkan pembentukan molekul $\mathrm{FeCNS}^{2+}$ yang ditunjukkan warna merah darah menjadi lebih pekat. Hal ini bila dikaitkan dengan persamaan reaksi yang ditulis, maka disebut reaksi bergeser ke kanan.

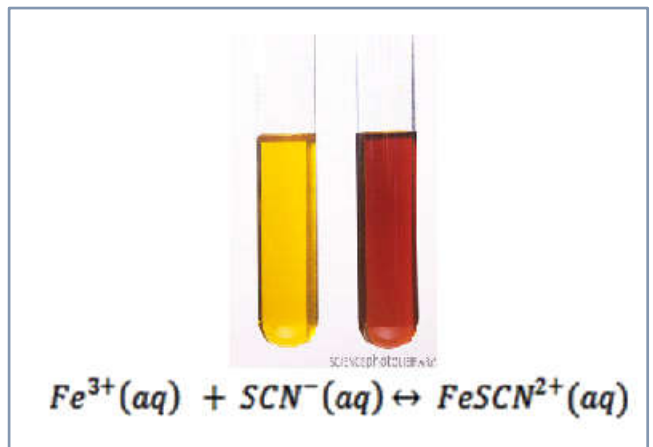

Gambar 2. Proses inkuiri siklus 1(2), kesetimbangan sistem Fe-tiosianat 
J. Pijar MIPA, Vol. VII No.2, September : 65 - 73

Aksi penambahan $\mathrm{Ag}^{+}$merupakan aksi pengurangan ion $\mathrm{CNS}^{-}$, hal ini disebabkan sebagian ion $\mathrm{CNS}^{-}$diikat oleh ion $\mathrm{Ag}^{+}$membentuk AgCNS. Akibatnya untuk mempertahankan sistem kesetimbangan, maka ion CNS- harus ditingkatkan dengan cara menguraikan ion $\mathrm{FeCNS}^{2+}$ dengan persamaan reaksi

$$
\mathrm{FeCNS}^{2+}(\mathrm{aq}) \rightarrow \mathrm{Fe}^{3+}(\mathrm{aq})+\mathrm{CNS}^{-}(\mathrm{aq})
$$

Berdasarkan persamaan reaksi kesetimbangan yang ditulis, maka reaksi penguraian ion $\mathrm{FeCNS}^{2+}$ merupakan reaksi ke arah kiri, sehingga disebut pergeseran ke arah kiri

Aktivitas dalam kegiatan siklus 2 adalah proses inkuiri untuk menemukan persamaan kesetimbangan pada sistem Fetiosianat (gambar 3)
Dalam kasus ini zat yang dapat dihitung berdasarkan pengukuran data percobaan adalah $\left[\mathrm{FeCNS}^{2+}\right]$, karena zat tersebut berwarna sehingga dapat ditentukan dengan metode kolorimetri. Dalam metode kolorimetri terdapat hubungan antara warna larutan, ketebalan larutan, dan konsentrasi $\operatorname{larutan} l=l x \in$ dimana $\mathrm{I}=$ kekuatan warna (terang/gelap), $1=$ ketebalan larutan, dan $\mathrm{c}=$ konsentrasi larutan

Persamaan tersebut mengandung arti bahwa untuk larutan yang konsentrasinya sama, makin kecil ketebalannya, maka warna larutannya makin terang. Hal yang sama bila suatu larutan memiliki tingkat terang sama maka perbandingan ketebalan larutan sama dengan perbandingan konsentrasi

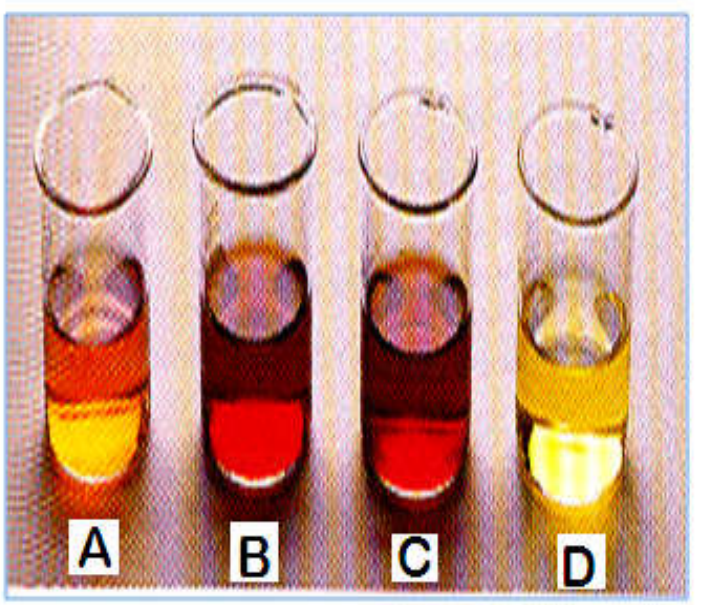

\section{Gambar 3. Proses inkuiri siklus 2: A, B, C, D adalah larutan FeCNS ${ }^{2+}$ dalam sistem setimbang dengan konsentrasi berbeda-beda}

Persamaan kesetimbangan pada sistem Fe-tiosianat dapat dinyatakan dalam persamaan i, ii, atau iii berikut:

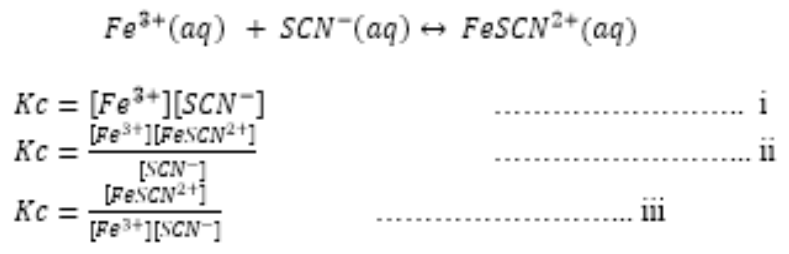

Persamaan yang tepat tidak dapat ditentukan dengan melihat persamaan reaksi yang ditulis, tetapi dihitung berdasarkan percobaan. Tahapan yang harus dilalui adalah menentukan konsentrasi zat saat setimbang yaitu $\left[\mathrm{FeCNS}^{2+}\right]$, $\left[\mathrm{Fe}^{3+}\right]$, dan [CNS-]. Penentuan konsentrasi zat dalam keadaan setimbang ada yang dapat diukur langsung dengan metode analisis kimia dan ada yang dihitung berdasarkan konsentrasi zat lain yang telah diketahui berdasarkan perhitungan stoikiometri.

$$
\frac{l_{2}}{l_{2}}=\frac{C_{2}}{C_{2}} \text { atau } C_{2}=\frac{l_{2}}{l_{1}} \times C_{1}
$$

dimana: $\mathrm{C}_{2}=$ konsentrasi larutan yang dicari, $\mathrm{C}_{1}=$ konsentrasi larutan yang telah diketahui, 11 dan 12 masing-masing tinggi/ketebalan larutan yang diperoleh dari pengukuran

Berdasarkan konsep tersebut di atas maka aktivitas inkuiri yang dinilai adalah: (1) melakukan proses reaksi kimia pada sistem kesetimbangan dengan konsentrasi berbeda - beda, (2) melakukan pengamatan warna dan kaitannya dengan pengukuran ketebalan larutan, (3) menggunakan data ketebalan larutan untuk menghitung konsentrasi $\mathrm{FeCNS}^{2+}, \mathrm{Fe}^{3+}$, dan $\mathrm{SCN}^{-}$ dalam larutan, (4) menginterpretasi data dalam hal ini mengkaitkan hubungan antara konsentrasi zat saat setimbang dengan nilai Kc, (5) mengambil kesimpulan hubungan nilai Kc yang diperoleh dengan persamaan kesetimbangan. Berdasarkan data yang diperoleh maka nilai aktivitas pada siklus 2 adalah meningkat 
UPAYA MENINGKATKAN KUALITAS PROSES DAN HASIL BELAJAR .... (Jeckson Siahaan, Muti'ah, Sukib)

dari 1,81 (60,33\%) siklus 1 (1) ke 2,06 (68,67\%) siklus $1(2)$ dan siklus 2 sebesar 2,56 atau $85,33 \%$

Aspek aktivitas yang paling rendah pada konsep yang diteliti adalah pengamatan warna larutan. Hal dapat disebabkan oleh kesalahan konsep akibat belum adanya konsep tentang hubungan antara warna, ketebalan, dan konsentrasi. Akibat kekurangtepatan dalam mengamati warna, maka berakibat kesalahan pengukuran ketebalan larutan dan menghasilkan perhitungan konsentrasi yang kurang tepat. Namun demikian mahasiswa menyadari tentang kesalahan yang dialami, sehingga mahasiswa mampu memprediksi tujuan akhir dari proses tersebut yaitu menentukan persamaan kesetimbangan.

Dari hasil pembahasan tentang aktivitas mahasiswa dalam melakukan proses inkuiri dalam kegiatan di laboratorium melalui bimbingan dosen maka aktivitas dapat ditingkatkan, karena dosen dapat memberi penekanan pada bagian-bagian yang sulit

Prestasi Belajar Mahasiswa
Nilai hasil belajar mahasiswa pada setiap siklus dapat dilihat dalam tabel 2 dimana nilai rata-rata dan standar deviasi masing-masing adalah sebesar 57,19 $(16,93)$ pada siklus 1 dan $71,20(16,43)$ pada siklus 2. Dari data ini menunjukkan bahwa pemberian tindakan pembelajaran inkuiri terbimbing dalam kegiatan di laboratorium dapat meningkatkan pemahaman mahasiswa dalam konsep kesetimbangan kimia. Namun demikian secara kuantitas, masih terdapat kesalahan konsep bagi mahasiswa. Untuk mengkajinya maka perlu ditinjau kembali bentuk pertanyaan yang diberikan tabel 4 . Berdasarkan data yang diperoleh pada siklus - 1, nilai rata-rata prestasi belajar hanya 57,19. Hal ini menunjukkan bahwa masih adanya kesalahan konsep pada beberapa mahasiswa. Terutama adalah konsep tentang keadaan setimbang secara mikroskopis. Mereka tidak dapat membedakan antara pengertian setimbang secara dinamis dan statis. Kesetimbangan dinamis adalah keadaan setimbang yang secara mikroskopis proses tetap berlangsung terus menerus dengan arah yang berlawanan.

Tabel 4. Tes Hasil Belajar Mahasiswa

Siklus - 1: Diketahui ion kromat mengalami reaksi setimbang dengan ion bikromat dengan persamaan sebagai berikut

$$
2 \mathrm{CrO}_{4}=+2 \mathrm{H}^{+} \quad+\quad \mathrm{Cr}_{2} \mathrm{O}_{7}====\quad+
$$

1. Pengertian keadaan setimbang dalam reaksi kimia secara mikrokospis (keadaan molekul yang terlibat) adalah

a. Reaksi berhenti

b. Reaksi berlangsung terus menerus dari kiri ke kanan dan dari kanan ke kiri

c. Konsentrasi zat yang terlibat berubah-ubah

d. Tidak dapat dipengaruhi oleh konsentrasi zat, tekanan, volume dan suhu

2. Kemana arah pergeseran kesetimbangan reaksi tersebut di atas bila ke dalam larutan ditambahkan $\mathrm{H}^{+}$. Jelaskan

3. Kemana arah pergeseran kesetimbangan bila ke dalam larutan ditambahkan $\mathrm{OH}^{-}$? Jelaskan

Siklus - 2: Saat kita mengamati larutan $\mathrm{FeSCN}^{2+}$ yang berwarna merah darah dalam tabung reaksi, maka secara kimia dapat dituliskan dalam persamaan
$\mathrm{Fe}^{3+}(a q)+$
$\operatorname{SCN}^{-}(a q)====\operatorname{FeSCN}^{2+}(a q)$
Kuning pucat
tak berwarna
merah tua

1. Hal ini menunjukkan bahwa dalam larutan tersebut terdapat

a. ion $\mathrm{Fe}^{3+}$ saja

b. ion $\mathrm{SCN}^{-}$dan ion $\mathrm{Fe}^{3+}$

c. ion $\mathrm{FeSCN}{ }^{2+}$ saja

d. ion $\mathrm{SCN}^{-}$, ion $\mathrm{Fe}^{3+}$ dan $\mathrm{FeSCN}^{2+}$

2. Bila kita mencampurkan $5 \mathrm{ml}$ larutan $\mathrm{Fe}\left(\mathrm{NO}_{3}\right)_{3} 0.02 \mathrm{M}$ dan $5 \mathrm{Ml} \mathrm{KSCN} 0.002 \mathrm{M}$ (seandanya kedua zat tidak bereaksi maka setelah bercampur konsentrasi $\mathrm{Fe}\left(\mathrm{NO}_{3}\right)_{3}=0.01 \mathrm{M}$ dan $\left.\mathrm{KSCN}=0.001 \mathrm{M}\right)$. Tetapi kenyataannya kedua zat bereaksi membentuk $\mathrm{FeSCN}^{2+}$ (aq) sehingga larutan berwarna merah darah

Pilih pernyataan yang benar

a. $\quad$ konsentrasi $\mathrm{Fe}^{3+}$ setimbang adalah sebesar $0.01 \mathrm{M}$

b. $\quad$ konsentrasi $\mathrm{Fe}^{3+}$ setimbang adalah konsentrasi $\mathrm{Fe}^{3+}$ yang bereaksi dengan SCN untuk membentuk $\mathrm{FeSCN}^{2+}$

c. $\quad$ konsentrasi $\mathrm{Fe}^{3+}$ setimbang adalah sama dengan konsentrasi $\mathrm{FeSCN}^{2+}$ yang terbentuk

d. konsentrasi $\mathrm{Fe}^{3+}$ setimbang adalah konsentrasi $\mathrm{Fe}^{3+}$ semula dikurang konsentrasi $\mathrm{Fe}^{3+}$ yang bereaksi untuk membentuk FeSCN ${ }^{2+}$ 


\section{J. Pijar MIPA, Vol. VII No.2, September : 65 - 73}

Kesalahan konsep ke dua adalah dalam menjelaskan arti pergeseran akibat penambahan zat yang dalam hal ini adalah tidak dapat menjelaskan secara molekular akibat penambahan ion $\mathrm{H}^{+}$pada sistem kromat-bikromat

$$
2 \mathrm{CrO}_{4}=+2 \mathrm{H}^{+}=====\mathrm{Cr}_{2} \mathrm{O}_{7}=+\mathrm{H}_{2} \mathrm{O}
$$

Dalam reaksi tersebut penambahan ion $\mathrm{H}^{+}$dari luar akan memperbesar konsentrasi ion $\mathrm{H}^{+}$dalam sistem kesetimbangan, dengan demikian harus ada aksi untuk menguranginya. Cara yang digunakan adalah dengan jalan mereaksikan ion $\mathrm{H}^{+}$yang hadir dengan ion kromat untuk membentuk ion dikromat dan air menurut persamaan reaksi:

$$
2 \mathrm{H}_{2} \mathrm{CrO}_{4}+2 \mathrm{H}^{+} \rightarrow \mathrm{H}_{2} \mathrm{Cr}_{2} \mathrm{O}_{7}+\mathrm{H}_{2} \mathrm{O}
$$

Proses tersebut ditunjukkan oleh munculnya warna oranye yang semakin kuat dan berlangsung terus hingga mencapai keadan kesetimbangan baru. Hal yang sama adalah pada penambahan ion $\mathrm{OH}^{-}$, pada penambahan $\mathrm{OH}^{-}$, maka akan mengurangi ion $\mathrm{H}^{+}$. Akibatkan terjadi reaksi, yaitu penguraian ion dikromat menjadi kromat dan ion $\mathrm{H}^{+}$.

Prestasi belajar mahasiswa pada siklus 2 sudah mencapai 71,20. Hal ini menunjukkan masih terdapat kesalahan konsep bagi beberapa mahasiswa. Kesalahan konsep terutama dalam memahami keadaan setimbang dari suatu sistem kimia, yaitu sistem $\mathrm{FeCNS}^{2+}$ yang berwarna merah darah. Pemahaman mahasiswa keliru bahwa dalam sistem tersebut hanya ada ion $\mathrm{FeCNS}^{2+}$. Mereka tidak paham bahwa dalam sistem setimbang terjadi reaksi

$$
\begin{array}{lll}
\mathrm{Fe}^{3+}(a q)+ & \mathrm{SCN}^{-}(\mathrm{aq})==== & \mathrm{FeSCN}^{2+}(a q) \\
\text { Kuning pucat } & \text { ak berwarna } & \text { merah tua }
\end{array}
$$

Oleh karena itu zat yang ada adalah ion $\mathrm{Fe}^{3+}$, ion $\mathrm{SCN}^{-}$ dan ion $\mathrm{FeCNS}^{2+}$. Kesulitan tersebut sesuai dengan hasil penelitian Bergquist dan Heikkinen [10] kesuliatan siswa dalam memahami kesetimbangan kimia disebabkan karena tidak memahami keadaan mikroskopis dalam sistem kesetimbangan, tidak dapat memahami konsentrasi zat saat setimbang, kesulitan dalam melakukan perhitungan serta kurang memahami prinsip Le Chatelier.

\section{Sikap Mahasiswa Terhadap Pembelajaran}

Berdasarkan analisis hasil angket maka dapat ditemukan bahwa sebesar 26,2\% mahasiswa mengatakan sangat setuju, 63,8 setuju, 7,7 \% kurang setuju dan 2,2\% menyatakan tidak setuju terhadap pembelajaran inkuiri terbimbing dengan kegiatan di laboratorium. Berdasarkan data tersebut menunjukkan bahwa lebih dari $90 \%$ mahasiswa menyatakan setuju dengan pembelajaran yang diterapkan.
Keunggulan percobaan kimia dalam pembelajaran kimia dapat digunakan sebagai cara untuk mengurangi perbedaan pemahaman dan merupakan cara efektif untuk menarik perhatian/ memotivasi siswa, menumbuhkembangkan sifat ingin tahu, dan meningkatkan pemahaman pada konsep-konsep kimia.

\section{KESIMPULAN}

Kesimpulan yang diperoleh dari penelitian ini adalah sebagai berikut: Penerapan pembelajaran inkuiri terbimbing melalui kegiatan di laboratorium/eksperimen dapat meningkatkan aktivitas pembelajaran, prestasi belajar dan motivasi mahasiswa dalam mempelajari konsep kesetimbangan kimia.

Aktivitas proses inkuiri mahasiswa yang dinilai meliputi kegiatan melakukan percobaan, mengamati, menyajikan/ mengumpulkan data, menginterpretasi dan membuat kesimpulan. Nilai yang diperoleh masing-masing adalah 60,33\% (siklus 1(1), $68,66 \%$ (siklus 1(2) dan 85,33\% (siklus 2). Prestasi/hasil belajar mahasiswa dalamm memahami konsep pergeseran dan persamaan kesetimbangan meningkat, yaitu sebesar 57,19 (siklus 1) dan 71,20 pada siklus 2. Motivasi/sikap mahasiswa terhadap penerapan metode pembelajaran inkuiri terbimbing cukup tinggi dengan rincian $26,2 \%$ menyatakan sangat setuju, 63,8 setuju, 7,7 \% kurang setuju dan $2,2 \%$ tidak setuju

\section{DAFTAR PUSTAKA}

[1] Anonim, 2003. Pendekatan Konstektual (Contextual Teaching and Learning CTL,. Depdiknas Didasmen, Direktorat Pendidikan Lanjutan Pertama

[2] Johnson, E.B., 2002. Contextual Teaching and Learning. California: Corwin Press Inc.

[3] Davodowitz, B. dan Rollnick, M., 2001. The Use of Flow Diagrams as an Effective Strategy for Learning in Laboratories, Australian Journal of Education in Chemistry, $57: 18-24$

[4] Bowen, C.W. dan Phelps, A.J., 1997. Demonstration-Base Cooperative Testing in General Chemistry: A Broader Assessment-of-Learning Technique. Journal of Chemical Education, 74(6) : 715 - 726

[5] Rollinck, M., Zwane, S., dan Green, G., 2001. Improving Pre-laboratory Preparationof First Year University Student Chemistry, International Journal of Science Education, 23(10): 1053 - 1071

[6] Huddle, P.A. dan Pillay, A.E., 1996. An in-dept Study of Misconceptions in Stoikhiometry and Chemical 


\section{UPAYA MENINGKATKAN KUALITAS PROSES DAN HASIL BELAJAR}

wquilibrium at a South African University, Journal of

Research in Teaching. 33: 65-77)

[7] Quilez, J., 1995. Student's and Teachers Misconception of Le Chatelier's Principles: Implications for Teaching of Chemical Equilibrium. Journal Research in Science Teaching, 12:939-957

[8] Johnstone, A.H. dan Al-Shuaili, A., 200. Learning in the Laboratory. U. Chem.Ed, 5: $42-51$

[9] Kemmis, S. dan R. McTaggart. 2000. The Action Research Planner, 3nd Edition. Victoria. Deakin University Press.

[10] Bergquist, W. dan Heikkinen H., 1990. Student Idea Regarding Chemical Equilibrium, Journal of Chemical Education. 67(12): 1000-1003 